\title{
A case report of young hypertensive with primary amenorrhea: uncommon variant of congenital adrenal hyperplasia
}

\author{
Divendu Bhushan $^{1}$, Mukta Agarwal $^{2}$
}

\author{
${ }^{1}$ PARAS, HMRI Hospital, Patna, Bihar, India \\ ${ }^{2}$ Department of Obstetrics and Gynaecology, AIIMS, Patna, Bihar, India
}

Received: 06 August 2015

Accepted: 21 August 2015

*Correspondence:

Dr. Divendu Bhushan,

E-mail: divenub@gmail.com

Copyright: $(\odot$ the author(s), publisher and licensee Medip Academy. This is an open-access article distributed under the terms of the Creative Commons Attribution Non-Commercial License, which permits unrestricted non-commercial use, distribution, and reproduction in any medium, provided the original work is properly cited.

\begin{abstract}
Hypertension in young should be evaluated in detail because secondary causes are more common in this subset of patients. As on one hand it help us in treating blood pressure and its complications including stroke, coronary artery disease and renal failure, other hand we should also treat the other complications like growth, puberty and electrolyte imbalance. Here we present a case who admitted in cardiology unit with accelerated HTN and hypokalaemia, and on detailed evaluation found to have primary amenorrhea. Identification of the cause not only leads to correct hypertension with minimal drugs but she got the reason of her amenorrhea.
\end{abstract}

Keywords: Hypertension, Hypokalaemia, 17 A Hydroxylase, Primary amenorrhea

\section{INTRODUCTION}

Congenital adrenal hyperplasia (CAHs) is the most common adrenal steroid genic defects, transmitted autosomal recessive traits. There are two types of hypertensive CAH- 1) $11 \beta$ hydroxylase deficiency and 2) $17 \alpha$ hydroxylase deficiency. Clinically these two can be differentiated on the basis of secondary sexual characters. Genetically female individual will virilised in former and having infantile sexual features in later. Genetic male will be unchanged in former and having ambiguous genitalia in later. Both will present as hypertensive and have hypokalaemia. Here we present a case that presented in emergency room with hypertension and weakness, and was treated for the same with multiple antihypertensive medicines for years.

\section{CASE REPORT}

A 24 year old female admitted in cardiology unit with giddiness, palpitation and generalised weakness. On examination she was found to have high BP $(160 / 100$ $\mathrm{mm} \mathrm{Hg}$ ).
No other significant finding present in general and systemic examination. On investigation she was having low S. K+ (2.6 MEq/L), with no other remarkable report. She was given tab amlodipine, tab telmisartan and monotrate, but had no relief. So for work up of secondary hypertension, she was sent to endocrine opd.

On reviewing the history it revealed that she was twin sister born, and her sibling sister expired after 2-3 weeks due to unknown cause. She is amenorrhic till now. She was investigated for primary amenorrhea by a gynaecologist which revealed that her uterus was hypo plastic and has atrophic ovaries.

On examination she was $189 \mathrm{~cm}$ tall with upper seg / lower seg: 92/97 and arm span was $193 \mathrm{~cm}$. Her MPH was $168 \mathrm{~cm}$. Her secondary sexual characters were normal. Till now her CBC (Hb: 12 gm. \%, TLC: 10,700/ cumm, PC 2.23 lakh/cumm), KFT: normal with low s. $\mathrm{K}+2.6 \mathrm{Meq} / 1$. Normal ECG, 2D -ECHO and renal Doppler. In view of young hypertension with primary amenorrhea, we sent her hormonal profile, reports of which are as below: 
1. S. TSH: $3.74 \mathrm{uIU} / \mathrm{ml}(0.35-5.5)$

2. S. Prolactin: $6.44 \mathrm{ng} / \mathrm{ml}$ (2.8- 28, non-pregnant state)

3. S. LH: $17.52 \mathrm{mIU} / \mathrm{ml}$ ( follicular phase 1.9-12.5,

i. luteal phase $(0.5-16.9)$

4. S. FSH: $49.92 \mathrm{mIU} / \mathrm{ml}$ ( follicular phase $2.5-10.2$, luteal phase 1.5-9.1)

5. S. PROGESTERONE: $7.42 \mathrm{ng} / \mathrm{ml}$ (foll phase 0.15-1.4, luteal phase 3.34-25.5)

6. S. ESTRADIOL: $34.2 \mathrm{pg} . / \mathrm{ml}$ (foll phase 18.9 246, luteal phase 22.4-256)

7. Plasma Renin Activity: 0.03(1.31-3.91) $\mathrm{mg} / \mathrm{ml} / \mathrm{hr}$. standing

$$
\text { i. }(1.55-2.33) \text { supine }
$$

8. S. Aldosterone: $5.5(1-10) \mathrm{mg} / \mathrm{dl}$ resting

9. Urinary VMA: 8.40(0-13) mmol/ $24 \mathrm{hrs}$.

These reports suggest $\mathrm{CAH}$ with HTN, so for further evaluation, we sent her $18(\mathrm{OH})$ corticosterone and deoxycorticosterone, reports of which were 196( range : 4-21 ng/dl supine,5-46 upright) and266(range: 1.5-8.5 $\mathrm{ng} / \mathrm{ml}$ in follicular phase, $3.5-13$ in luteal phase).

After confirming diagnosis, she was put on tab dexamethasone $(0.5 \mathrm{mg})$ and tab spironolactone $50 \mathrm{mg}$. She responded well to the treatment and BP come down to $120 / 70 \mathrm{mmHg}$. She is in follow up for past 2 years and presently she is on $0.25 \mathrm{mg}$ dexamethasone and aldactone $50 \mathrm{mg}$ and not having any side effect. Her elder sister is also having infertility, but she didn't turn up for evaluation.

\section{DISCUSSION}

Congenital adrenal hyperplasia was described in literature since 1865 when DE Crecchio's described his autopsy finding of a napolian pseudohermaphrodite who had female internal organ and ductal structure in a phenotypic male. ${ }^{1}$ These adrenal steroidogenic defects are transmitted as autosomal recessive traits. The specific form of $\mathrm{CAH}$ are identified by the abnormal patterns of glucocorticoids, mineralocorticoids and sex hormones and accompanying clinical features including abnormal foetal genital development, disturbances in sodium homeostasis and, blood pressure regulation, and post natal consequences of sex steroid imbalance affecting somatic growth and fertility.

As per literature search in Pub med in April 2015, this case is 2nd one in India and this $\mathrm{CAH}$ variant is $1 \%$ of all CAH cases. ${ }^{2}$ The first case was described from Andhra Pradesh where a young female presented with hypokalemic paralysis and finally diagnosed to have $17 \alpha$ hydroxylase deficiency. ${ }^{10}$

17- $\alpha$-hydroxylase act through: (i) it hydroxylates pregnenolone and progesterone in the 17 position; and (ii) cleaves the steroid side-chains from 17hydroxypregnenolone $(17,20$ lyase activity) to convert it to the $\mathrm{C}-19$ androgen precursor, DHEA. ${ }^{3}$ Deficiencies in
CYP17 result in decreased synthesis of cortisol, C-19 androgens (dihydroepiandrosterone and androstenedione) and sex hormones. Adrenal insufficiency (due to decreased cortisol synthesis) does not manifest as classical Addison's disease because of increased production of corticosterone, a weaker glucocorticoid. This results in an increase in ACTH secretion, which in turn leads to increased synthesis of steroid intermediates, such as progesterone, 17- $\alpha$-deoxysteroids (deoxycorticosterone [DOC] and corticosterone. ${ }^{4}$ This overproduction of ACTH leads to adrenal hyperplasia. DOC has a potent mineralocorticoid action and causes retention of sodium and water, hypokalaemia, alkalosis, and hypertension. In consequence, the renin-angiotensin system is usually suppressed, resulting in decreased aldosterone synthesis leading to a state of hyporeninemic hypoaldosteronism. ${ }^{5}$

Table 1: Clinicobiochemical comparison of different enzymes involved in steroidogenesis.

\begin{tabular}{|c|c|c|c|}
\hline & $\begin{array}{l}17 \alpha \\
\text { hydroxyla } \\
\text { se } \\
\text { deficiency }\end{array}$ & $\begin{array}{l}17 \text { a/17,20 lyase } \\
\text { combined } \\
\text { deficiency }\end{array}$ & $\begin{array}{l}11 \beta \\
\text { hydrox } \\
\text { ylase } \\
\text { deficien } \\
\text { cy }\end{array}$ \\
\hline HTN & + & \pm & + \\
\hline Hypokalaemia & + & \pm & + \\
\hline $\begin{array}{l}\text { External } \\
\text { genitalia } \\
\text { XX } \\
\text { XY }\end{array}$ & $\begin{array}{l}\text { female } \\
\text { male }\end{array}$ & $\begin{array}{l}\text { Infantile female } \\
\text { Ambiguous genitalia }\end{array}$ & $\begin{array}{l}\text { virilised } \\
\text { male }\end{array}$ \\
\hline $\begin{array}{l}\text { Diagnostic } \\
\text { test }\end{array}$ & $\begin{array}{l}\uparrow \text { corticoste } \\
\text { rone, } \\
18(\mathrm{oh}) \\
\text { DOC, low } \\
\text { renin, } \\
\text { Low to } \\
\text { normal s. } \\
\text { aldosteron } \\
\text { e }\end{array}$ & $\begin{array}{l}\text { Low } \\
\text { androgen/estrogen } \\
, \uparrow \text { corticosterone }\end{array}$ & $\begin{array}{l}\uparrow 11 \\
\text { deoxyco } \\
\text { rtisol }\end{array}$ \\
\hline
\end{tabular}

For genital organs development, the two enzymes, $17 \alpha-$

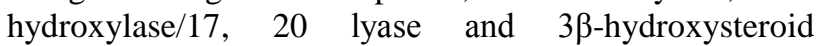
dehydrogenase, in both the adrenals and gonads are shared in sexual maturity throughout foetal life and puberty. Thus in CAH due to $17 \alpha$-hydroxylase deficiency, there will be an impairment of both adrenal and gonadal steroid hormones (androgens and estrogens).

A single enzyme P450c17 catalyses both the conversion of mineralocorticoid to glucocorticoid (17 $\alpha$ hydroxylase activity) and the conversion of glucocorticoid to sex steroid (17, 20 lyase activity). Pure $17 \alpha$ hydroxylase deficiency would be present with hypokalemic hypertension with alkalosis, possibly with normal sexual development. In combined deficiency patients doesn't present as adrenal crises due to high corticosterone and diagnosed only when investigated for abnormal pubertal 
development. $^{6}$ In the genetic male, there is psedohermaphroditism, where as in female infantile genitalia are present. $^{7}$ In female at pubertal age, no secondary sexual character develop, and there in primary amenorrhea. Phenotypically such patients may be similar to individuals with androgen insensitivity syndrome.

Hypertension is observed in the $17 \alpha$ hydroxylase def. and $11 \beta$ hydroxylase def. form of $\mathrm{CAH}$. The serum level of DOC is markedly elevated (30 to 60 times) in former. As in 21- hydroxylase def., sibling pair expected to have a common genetic defect do not always exhibit the same biochemical findings. ${ }^{8}$

Hypertension and hypokalaemia responded to glucocorticoid treatment. Glucocorticoids suppress the high ACTH-induced mineralocorticoid excess. ${ }^{9}$ Mineralocorticoid antagonist, such as spironolactone and calcium channel blockers can be added to the regimen for better control of BP.

Hormone replacement regimens have to start early in adolescence to allow development of secondary sexual characteristics and stimulate normal anabolic bone mass of puberty. The 46,XX patients usually require combined/cyclic estrogen/progestin therapy to prevent endometrial hyperplasia from unopposed estrogen and are often treated with estrogen alone if they first come to medical attention at the time of puberty, or at diagnosis if that time has passed and with the decision to be reared as female.

Our patient was maintained on dexamethasone $0.25 \mathrm{mg}$ and aldactone $50 \mathrm{mg}$ daily. She was advised to take HRT but she is not compliant to it and taking only for withdrawal bleeding.

\section{CONCLUSION}

Although $17 \alpha$ hydroxylase is a very rare disorder, but one should think about this or keep a possibility of $\mathrm{CAH}$ in cases of young hypertensive with abnormal electrolyte. It is also very important to take detailed history including menstrual history, pubertal growth history in these young patients. Early diagnosis will lead to prevent complication of hypertension and make patients and their relatives to understand the nature of sexualism and treat infertility.
Funding: No funding sources Conflict of interest: None declared

Ethical approval: Not required

\section{REFERENCES}

1. De Crecchio L. Sopra UN caso di appearance virile in una donna.Morgagni. 1865;7:951.

2. Matteson KJ, Picado-Leonard J, Chung BC, Mohandas TK, Miller WL. Assignment of the gene for adrenal P450c17 (steroid 17 alphahydroxylase/17, 20 lyase) to human chromosome 10 . J Clin Endocrinol Metab. 1986;63(3):789-91.

3. Lin D, Harikrishna JA, More CC, Jones KL, Miller WL. Missense mutation series 106-proline causes 17 $\alpha$ Hydroxylase deficiency. J Biol Chem. 1991;266:15992-8.

4. Bigelieri E G, Herron M A, burst N. Male Pseudo hermaphroditism due to $17 \alpha$ Hydroxylase deficiency in man. J Clin Invest. 1966;45:1946-54.

5. Grumbach MM, Hughes IA, Conte FA. Disorder of sex differentiation. In: Larsen PR, Kronenberg HM, Melmed S, editors. Williams Textbook of Endocrinology. 10th ed. Philadelphia: Saunders; 2003. pp.842-1002.

6. Martin RM, Lin CJ, Costa EMF, et al: P450c17 deficiency in Brazilian patients: biochemical diagnosis through progesterone level confirmed by CYP17 genotyping. J ClinEndocrinol Metabol. 2003;88:5739-46.

7. Sills IN, Macgillivray MH, Amrhein JA, Migeon CJ, Peterson RE: 17 alpha hydroxylase deficiency in a genetic male and female sibling pair. Int $\mathrm{J}$ Gynaecol Obstet. 1981;19(6):473-9.

8. Yanase T, Simpson E, Waterman M: 17 ALPHAHYDROXYLASE/ 17, 20 LYASE DEF: from clinical investigation to molecular DE finition. Endocr Rev 1991;12:91-108.

9. Peter M, Sippell WG, Wernze H. Diagnosis and treatment of 17 a Hydroxylase deficiency. J Steroid Biochem Mol Biol. 1993;45:107-16.

10. SK Kota, KK Modi, R Jha, SN Mandal: 17 alpha hydroxylase def.: an unusual case with primary amenorrhea and hypertension. Indian $\mathrm{J}$ Endocrinol Metab. 2011;15(2):127-9.

Cite this article as: Bhushan D, Agarwal M. A case report of young hypertensive with primary amenorrhea: uncommon variant of congenital adrenal hyperplasia. Int J Reprod Contracept Obstet Gynecol 2015;4:1642-4. 